\title{
Bacteriological Quality of Milk in Raw Bovine Bulk Milk in the Selected Milk Collection Centers: Smallholder Dairy Processing Ethiopia
}

\author{
Hiwot $\mathrm{D}^{*}$, Savoinni $\mathrm{G}^{1}$, Cattaneo $\mathrm{D}^{1}$, Gabriella $\mathrm{S}^{2}$ and Martino $\mathrm{P}^{2}$ \\ ${ }^{1}$ Department of Veterinary Sciences for Health, Animal Production and Food Safety (VESPA), Italy \\ ${ }^{2}$ Department of Health, Animal Science and Food Safety, Section of Microbiology, Immunologia Veterinaria- DI- \\ PAV, University of Milan, Italy
}

${ }^{*}$ Corresponding author: Hiwot D and Cattaneo D, Department of Veterinary Sciences for Health, Animal Production and Food Safety (VESPA), University of Milan, Italy, E-mail: Joy_life2008@yahoo.com, donata. cattaneo@unimi.it

Citation: Hiwot D, Savoini G, Cattaneo D, Gabriella S, Martino P (2016) Bacteriological Quality of Milk in Raw Bovine Bulk Milk in the Selected Milk Collection Centers: Smallholder Dairy Processing Ethiopia. J Vet Sci Ani Husb 4(2): 201. doi: 10.15744/2348-9790.4.201

Received Date: October 26, 2015 Accepted Date: May 23, 2016 Published Date: May 25, 2016

\begin{abstract}
Cross-sectional study was conducted to examine and identify quality of raw bovine milk from in Arsi Zone and East Shewa Zone, in Oromia, Ethiopia. The purpose of the study was to assess hygienic practices during milking, milk collection and bacteriological quality of cow's milk in Arsi and East Shewa Zones milk collection centers. Total of 246 bacterial isolates were obtained from milk samples taken from Tiyo, Digeluna Tijo, and Lemuna Bilbilo Districts in Arsi Zone and Ada district in East Shewa Zone. Identification of Escherichia coli done using API 20 E biochemical test kit, Gram stain was used to identify staphylococcus aureus, Listeria was identified using Rapid Listeria monocytogenes (RLM), and Brucella identified using Milk ring test (MRT). These included Escherichia coli 19.8\%, Listeria monocytogenes $1.2 \%$, Staphylococcus aureus $3.2 \%$ and Brucella $3.3 \%$.
\end{abstract}

Keywords: Husbandry practices; Milk; Bacteriological quality

List of abbreviations: AFC: Age at First Calving; AI: Artificial Insemination, CI: Calving Interval; NVI: National Veterinary Institute

\section{Introduction}

In Ethiopia, the traditional milk production system, which is dominated by indigenous breeds of low genetic potential for milk production, accounts for about $97-98 \%$ of the country's total annual milk production [1]. Cows are the main source of milk, and as a result, it is cow's milk that is the focus of processing in Ethiopia. However, due to the fact that dairy processing in the country is basically done at the smallholder level, standards of products are generally poor [2]. Raw milk is either kept at ambient temperature or kept in a warm place to ferment [3].

One of the most common food sources in the human diet is milk [4]. Physical, chemical, and biological characteristics of milk favor the multiplication of many bacteria of various genera (Turner and Veary, 1990). This is especially true in developing countries where production of milk and various dairy products take place under rather unsanitary conditions [2]. Microbial contamination of milk and milk products can occur due to unhygienic conditions; the possible source for contaminations are the conditions within the udder, exterior to the udder, the milk handling and its storage equipment [5].

Post-harvest spoilage losses of about $40 \%$ have been reported from milking to consumption. Such losses are mainly attributed to the employment of hygienic practices at the time of milking, long storage time at high ambient temperature, adulteration of milk, transportation equipment and distribution systems, which leads to losses in spillage, bacterial contamination and spoilage of milk [1].

In Ethiopia, in most cases, milk is produced and marketed without quality control measures [2]. Information on the microbial and chemical properties of raw milk and milk products produced and marketed by smallholder producers is essential to understand the overall quality of the products being marketed and consumed.Therefore the objectives of this study were to assess bacteriological quality of raw milk and to determine some associated determinants and sources of contamination of raw milk [6]. 


\section{Methods and Materials}

\section{Study Area Description}

Arsi and EastShewa Zones were chosen for the study due to their comparative potential for improved dairy production and dairy production in particular contribute significantly to farmer livelihoods.

Baseline information gathering was conducted in Arsi Zone (Tiyo, DigelunaTijo, and LemunaBilbilo Districts) and East Shewa Zone (Ada district).

Tiyo district: - is located at about $167 \mathrm{~km}$ south east of Addis Ababa and at the foot slopes of Mount Chilalo in the eastern side. Tiyo has diverse climatic conditions; Midland (weynadega) (52\%), Highland (dega) (37\%), and Lowland (kola) (11\%) agro- ecologies with altitude ranging from below 2300 to over 3200 meters above sea level.

DigelunaTijo is located $192 \mathrm{~km}$ from the capital Addis Ababa in the southeast. The district has diverse climatic conditions; Highland (dega) (78\%) and Midland (weynadega) (22\%) agro-ecologies with altitude ranges from 2500 to 3560 meters above sea level.

LemunaBilbilo is located $223 \mathrm{~km}$ from the capital Addis Ababa in thesoutheast. The district has climatically diverse conditions; Highland (dega) (80\%) and Midland (weynadega) (17\%) and Lowland (kola) (3\%) agro-ecologies with altituderanges from 2500 to 3560 meters above sea level.

Ada is located 47.9 kilometers southeast of Addis Ababa. About $90 \%$ of the district belongs to the sub-tropical agro-climatic zone. The tropical and temperate agro-climatic zones cover 5\% of the district each. Under Ada district the following kebeles Lemlem, Kebele 02, Kebele 11, Denkaka and Babugaya were selected.

\section{Study Population}

Cross-sectional study design was used to assess the husbandry practices, hygienic status of milk production and transportation. 201 cooperative member farmers were individually interviewed. The milk production, handling and hygienic practices employed, and other conditions thought to affect the hygienic quality of milk were assessed. The approximate sample size required was estimated using the formula given by Arsham, (2005) for survey studies and milk sample collection:

$\mathrm{N}=0.25 / \mathrm{SE}$, Where: $\mathrm{SE}=$ Standard error, $\mathrm{N}=$ required sample size

Hence, at 5\% standard error, a total number of 100 individual households were selected randomly for the baseline survey from each Zone making a total of 200 households in Arsi and East Shewa Zone.

Following proportional allocation, two milk collection centers (Assela town and Gobelencha) and one dairy farm (Del-Besira) were randomly selected in Arsi Zone and five milk collection stations (Kebele-11, Denkaka, Babugaya, Kebele- 02, Lemlem) were randomly selected in East Shewa Zone. A total of 106 milk samples were proportionally allocated to the selected milk collection centers. Milk samples were randomly collected from each collection center.

\section{Sample Collection and Transportation}

The study was conducted from February 2011 to January 2014 to assess the bacteriological quality of raw milk. Raw milk samples were collected from milk containers after milking for bacteriological analysis. The samples were collected aseptically in sterilized universal bottle, kept in an icebox and transported to National Veterinary Institute (NVI) microbiology laboratory and then stored in refrigerator at $4{ }^{\circ} \mathrm{C}$ to be analyzed within 24 hours of sampling.

\section{Bacteriological Laboratory Analysis}

Escherichia coli: One loop of milk was streaked on MacConkey agar plates, and then incubated at $37^{\circ} \mathrm{C}$ for 24 hours. Colonies that were pink colored were counted as presumptive Escherichia coli. Colonies picked from the MacConkey agar plates were re-streaked on fresh Eosin Methylene Blue (EMB) agar plates to purify and incubated at $37^{\circ} \mathrm{C}$ for 24 hours. Colonies that were made green with metallic shine were counted as presumptive Escherichia coli. These colonies were transferred to Trypticase soy agar (TSA) plate for the following, Gram-stain, oxidase test and catalase test. Gram negative, oxidase negative and catalase positive colonies were selected and used for identification of species. The identification was done using API 20 E biochemical test kit (BioMérieux, France).

Staphylococcus aureus: One loop of milk was streaked on Trypticase Soy Agar (TSA) plates, which then is incubated at $37^{\circ} \mathrm{C}$ for 24 hours. Those colonies that are white to golden yellow were counted as presumptive Staphylococcus species. Colonies picked from the Trypticase Soy Agar plates were re-streaked on fresh Trypticase Soy Agar plates to purify and then incubate at $37{ }^{\circ} \mathrm{C}$ for 24 hours. This was followed by Gram-stain, and catalase test. Gram-positive coccus as colonies were selected and used for biochemical test. Catalase positive, OxidationFermentation (OF) test positive and coagulase positive bacteria were confirmed as Staphylococcus aureus. 
Listeria monocytogenes: $25 \mathrm{ml}$ of milk sample was homogenized with $100 \mathrm{ml}$ of Half Fraser broth and incubated at $37{ }^{\circ} \mathrm{C}$ for 24 hours. After 24 hours the sample was transferred using a loop and streak over the surface of Rapid Listeria monocytogenes (RLM) agar plate and incubated at $37^{\circ} \mathrm{C}$ for 48 hours for further isolation. Colonies that are gray-blue, round and smooth precipitate were counted as Listeria monocytogenes. Colonies of Listeria monocytogenes were selected and used for species identification using Microgen Listeria ID.

Brucella - Milk ring test (MRT): $1 \mathrm{ml}$ of milk sample was put in a test tube and $3 \mu \mathrm{l}$ of the standard MRT antigen (killed B. abortus stained with hematoxylin) was added then mixed well. The mixture was incubated at $37^{\circ} \mathrm{C}$. Positive samples were identified as blue cream layer over stained milk while negative samples were identified as whitish cream layered over stained milk.

\section{Data Management and Analysis}

All the collected data were stored and managed in Microsoft Excel database. The data were analyzed using the statistical software SPSS (Version 16.0, 2006).

\section{Results}

\section{Milking and milk handling practices}

According to the survey result, all the respondents stated that they wash their hands before milking and most respondents (94.5\%) wash udder of the cow before milking and $85.6 \%$ of the respondents also indicated that they use towel for cleaning the teats before milking cows.

Large proportion of respondents (88.1\%) use plastic materials as milk container and transport, $8 \%$ use metallic materials and 3.5\% use traditional pots. Majority of the respondents in Arsi Zone (45.8\%) use plastic vessel and 3.5\% of the respondents use traditional pots. In East Shewa Zone majority of the respondents (43.3\%) use plastic vessel and the rest (7.5\%) use metal vessel.

\section{Water source and watering practices}

Respondent had two different water sources in both zones; these are river and tap water. Majority of the respondents in both zones (61.2\%) used tap water while $37.8 \%$ used river water and $1.0 \%$ of the respondents used both water sources. In Arsi Zone majority $37.8 \%$ used river as source of water while $49.8 \%$ respondents in East Shewa Zone used tap water as water source.

\section{Bacteriological Laboratory Analysis}

Among the bulk milk samples analyzed a total of 247 isolates were obtained including Enterobacteriaceae, Listeria, Staphylococcus and Brucella antibodies (Table 1).

\begin{tabular}{|c|c|c|}
\hline Type of bacteria & No of bacteria isolated & Percent prevalence \\
\hline Enterobacteriaceae & $\underline{92}$ & $\underline{37.2}$ \\
\hline E. coli & 49 & 19.8 \\
\hline Other Entro & 43 & 17.4 \\
\hline Listeria & $\underline{106}$ & $\underline{42.9}$ \\
\hline Listeria monocy & 3 & 1.2 \\
\hline Other Listeria & 103 & 41.7 \\
\hline Staphylococcus & $\underline{41}$ & $\underline{16.6}$ \\
\hline S. aureus & 8 & 3.2 \\
\hline Non patho Staph & 33 & 13.4 \\
\hline Brucella Positive & $\underline{8}$ & $\underline{3.3}$ \\
\hline Total & 247 & \\
\hline
\end{tabular}

Table 1: Pathogenic Bacteria isolates from 106 bulk milk samples from Asella Dairy Union and Ada Primary Dairy Cooperative, Ethiopia

Lemlem milk collection center showed higher Escherichia coli isolates followed by Kebele 02 and Denkaka in East Shewa Zone whereas lower isolates were found in Gobelench in Arsi Zone. Higher isolates of pathogenic Listeria monocytogenes was detected in Kebele 02 milk collection center East Shewa Zone. This is followed by Denkaka milk collection center in East Shewa Zone.

Isolates of Staphylococcus aureus were detected high in Babugaya and Lemlem milk collection centers in East Shewa Zone. Next higher isolates were found in Gobelencha, Arsi Zone and Kebele 02 in East Shewa Zone. Higher isolates of Brucella isolates were found in Kebele 02 milk collection center in East Shewa Zone. In Arsi Zone only Asella milk collection center showed Brucella isolates. 


\section{Discussion}

The present study shows that faulty handling, in some dairy farmers milking procedures, where there is no proper cleaning or washing of hands immediately before milking can lead to the contamination of the milk [7] and [8] noted that insufficiently cleaning the udder before milking and lack of other pre-milking hygienic preparations play an important role in the contamination of milk during milking. The current study further indicates that even those respondents who practiced washing their hands before milking, as well as the teats of the cows may not be much of guarantee for the safety of the milk. This is due to several factors. The cleaning is not properly done with clean and boiled water and disinfected to remove both visible dirt and bacteria, so it is not effective [9] and [10]. On top of this, it was clear that for few of the respondents, the cleanliness of the sources of their water is far from certain. They get their water from rivers which in most cases is not clean; the use of this water for cleaning hands and udder prior to milking won't avoid or prevent contamination of the milk. These are possible contributing factors for the high contamination of milk during milking in the current study area and for other problems ensuing from this.

Microbial contamination in raw milk depends not only on contamination during milking but also on the temperature at which milk is stored and on the time that elapses between milk production and collection [11]. As observed during the field work milk is transported by locally available means that may include transport by foot, donkey or public transport from farmers further than 10-20 kilometers away from cooperative centers, this very well defines high bacterial contamination in our study, which is due to long distance of milk transport to the cooperative center without cooling system results in rise of milk temperature, which spoils the milk within 3-4 hours. According to [12] the detection of bacterial contamination can also be attributed to higher environmental contamination during transportation and/or contamination during waiting along the roadside.

During transporting the milk to the cooperative centers, there is no chance of cooling the milk, as there is no cooling system in place; the first cooling of the milk is done at the milk cooperative centers. Major transport means of milk in current study area is by foot, horse/donkey, bicycle and public transport. The time that elapse between the milking time and the cooling of the milk has huge influence on the milk to be contaminated in line with the finding by $[13,14]$.

\section{Conclusion}

The present study shows the bacteriological, particularly with pathogenic microorganisms of raw bulk milk from milk collection centers. The presence of these pathogens in milk indicates that contamination comes from various sources such as unclean environment and utensils. The high numbers of the isolated microorganisms not only contaminate the milk but also multiply and grow in the milk. The occurrence of pathogens is likely to affect the keeping of quality and safety of raw milk as well as products derived from it. The presence of these pathogenic bacteria in raw milk is of public health concern since drinking raw milk is still considered good for health in rural population of the country.In general, the result of the study indicated that an urgent measures are needed to ensure clean and safe milk production and handling at farmer level and collection centers through trainings on hygienic practices and sanitary measures from production to consumption levels.

\section{Acknowledgements}

My deep acknowledgment and appreciation goes to National Veterinary Institute (NVI) for their wonderful support and assistance in my laboratory work; their technical support and their encouragement have made significant contributions to the successful analysis of the work in the laboratory. I would also like to thank the participants who contributed their time and energy to make this project successful.

\section{References}

1. Felleke G (2003) Milk and Dairy Products, Post-harvest Losses and Food Safety in Sub-Saharan Africa and the Near East. A Review of the Small Scale Dairy Sector - Ethiopia. FAO Prevention of Food Losses Programme. FAO, Rome, Italy.

2. Yilma Z, Faye B (2006) Handling and Microbial Load of Cow's Milk and Irgo - Fermented Milk Collected from Different Shops and Producers in Central Highlands of Ethiopia. Ethiopian J Anim Prod 6: 67-82.

3. Mogessie A (2002) The microbiology of Ethiopian foods and beverages: A review. SENET: Ethiopian J Sci 25: 97-140.

4. Grimaud P, Sserunjogi M, Wesuta M, Grillet N, Kato M, et al. (2009) Effects of season and agro-ecological zone on the microbial quality of raw milk along the various levels of the value chain in Uganda. Trop Anim Health Prod 41: 883-90.

5. Parekin TS, Subhash R (2008) Molecular and bacteriological examination of milk from different animals with special reference to coliforms. Curr Res Bacteriol 1: $56-63$.

6. Olatunji EA, Jubril AE, Okpu EO, Olafadehan OA, Ijah UJ, et al. (2012) Bacterial Assessment and Quality Analysis of Raw Milk Sold in Gwagwalada Area Council of the Federal Capital Territory (FCT) Abuja, Nigeria. Food Sci Quality Manage 7.

7. Galton DM, Petersson LG, Merril WG (1986) Effects of Pre Milking Udder Preparation Practices On Bacterial Counts In Milk And On Teats. J Dairy Sci 69: 260-6.

8. Gonfaa A, Howard A Foster, Wilhelm H (2001) Field Survey and Literature Review on Traditional Fermented Milk Products of Ethiopia. Int J Food Microbiol 68: 173-86.

9. Chye FY, Abdullah A, Ayob MK (2004) Bacteriological Quality and Safety of Raw Milk in Malaysia. Food Microbiol 21: 535-41. 
10. Millogo V, Sjaunja KS, Ouedrago GA, Agenas S (2010) Raw Milk Hygiene at Farms, Processing Units and Local Markets in Burkina Faso. Food control 21: 1070-4.

11. Ahmed AI, Mohammed AA, Faye B, Blanchard L, Bakheit SA (2010) Assessment of Quality of Camel Milk andGariss, North Kordofan State, Sudan. Res J Anim Vet Sci 5: 18-22.

12. Garedew L, Berhanu A, Mengesha D, Tsegay G (2012) Identification Of Gram-Negative Bacteria From Critical Control Points Of Raw And Pasteurized Cow Milk Consumed At Gondar Town And Its Suburbs, Ethiopia. BMC Public Health 12: 950.

13. Bonfoh B, Wasem A, Traoré AN, Fané A, Spillmann H, et al. (2003) Microbiological Quality Of Cow’s Milk Taken At Different Intervals From Theudder To The Selling Point In Bamako (Mali). Food Control 14: 495-500.

14. Millogo V, Ouédraogo GA, Agenäs S, Svennersten-Sjaunja K (2008) Survey on Dairy Cattle Milk Production and Milk Quality Problems inPeriUrban Areas in Burkina Faso. Af J Agri Res 3: 215-224.

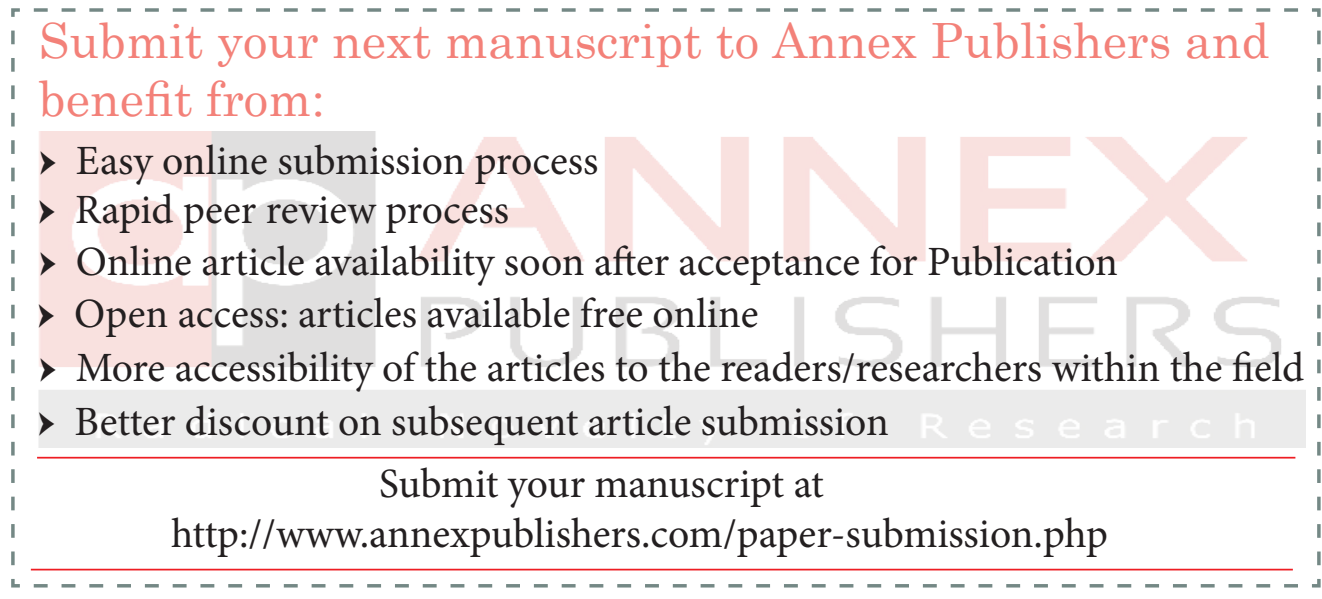

